\title{
EFFECT OF VARIED NPK FERTILIZATION ON CATALASE ACTIVITY OF AMARANTH (AMARANTHUS CRUENTUS L.)
}

\author{
WPLYW ZRÓŻNICOWANEGO NAWOŻENIA NPK NA AKTYWNOŚĆ \\ KATALAZY AMARANTUSA (AMARANTHUS CRUENTUS L.)
}

\begin{abstract}
A study was carried out on the effect of varied NPK fertilization on catalase activity per gram fresh weight of the leaves of two varieties of amaranth, Rawa and Aztek, at different developmental stages (seedling, five-leaf, flowering and mature seed), as well as in the seeds. Amaranth was grown in a field experiment in southeast Poland, at wide-row spacing on good wheat complex soil. The following combinations of macronutrient levels were applied: I - $50 \mathrm{~kg} \mathrm{~N} \cdot \mathrm{ha}^{-1}, 40 \mathrm{~kg} \mathrm{P} \cdot \mathrm{ha}^{-1}, 40 \mathrm{~kg} \mathrm{~K} \cdot \mathrm{ha}^{-1}$, II $-70 \mathrm{~kg} \mathrm{~N} \cdot \mathrm{ha}^{-1}, 50 \mathrm{~kg} \mathrm{P} \cdot \mathrm{ha}^{-1}$, $50 \mathrm{~kg} \mathrm{~K} \cdot \mathrm{ha}^{-1}$, III $-90 \mathrm{~kg} \mathrm{~N} \cdot \mathrm{ha}^{-1}, 60 \mathrm{~kg} \mathrm{P} \cdot \mathrm{ha}^{-1}, 60 \mathrm{~kg} \mathrm{~K} \cdot \mathrm{ha}^{-1}$ and IV $-130 \mathrm{~kg} \mathrm{~N} \cdot \mathrm{ha}^{-1}, 70 \mathrm{~kg} \mathrm{P} \cdot \mathrm{ha}^{-1}$, $70 \mathrm{~kg} \mathrm{~K} \cdot \mathrm{ha}^{-1}$. The study showed that catalase activity exhibited a downward trend during the vegetation period of amaranth. The highest catalase activity was noted in the leaves during the first stage, ie the seedling stage. Increasing levels of NPK led to an increase in catalase activity. Leaves of the Rawa variety had higher catalase activity than those of the Aztek variety at every stage of development. The level of catalase activity in the amaranth seeds was also significantly affected by fertilization and the variety of amaranth. Higher levels of the fertilizers caused an increase in catalase activity in the seeds.
\end{abstract}

Keywords: amaranth, catalase activity, leaves, seeds

Amaranth (Amaranthus cruentus L.) is a crop that responds to macronutrient fertilizers with very rapid increases in biomass yield and seed yield. In Poland, mainly seed varieties of amaranth are cultivated. Amaranth seeds have a good chemical composition, are rich in proteins, fats and dietary fibre, and are also a valuable source of antioxidant compounds, such as squalene, tocopherols, and tocotrienols [1,2]. They are increasingly recommended in the diet of both healthy and sick people [3]. The aerial parts of the plant can be used as vegetables and for animal feed. Amaranth leaves can be consumed in a variety of ways, eg raw, blanched or boiled. They have very high nutritional value - they contain from 17.4 to $38 \%$ protein in dry weight, rich in exogenous amino acids, with fat content ranging from 1 to $10 \%$ and raw fibre from 5.4 to $24.6 \%$ in dry weight, depending on the species of amaranth [4]. The most important minerals in amaranth leaves include calcium (Ca), potassium $(\mathrm{K})$, magnesium $(\mathrm{Mg})$ and iron $(\mathrm{Fe})$. However, their assimilability may be limited

\footnotetext{
${ }^{1}$ Faculty of Agricultural Sciences in Zamość, The University of Life Sciences in Lublin, ul. Szczebrzeska 102, 22-400 Zamość, Poland, phone +48 846772756

*Corresponding author: barbara.skwarylo@up.lublin.pl
} 
by the presence of oxalates in the leaves [4]. A particularly pronounced increase in biomass yield is observed when varieties of amaranth used as vegetables or for animal feed are fertilized with nitrogen [5]. Excessive use of nitrogen fertilizer can affect the suitability of amaranth leaves for use as food or fodder, as it causes nitrates to accumulate in the aboveground biomass [6], which is harmful to humans and animals. Excess nitrogen fertilizer can induce oxidative stress in the plant and alter the activity of enzymes protecting it against reactive oxygen species. Catalase is one of the most important enzymes participating in the regulation of growth and development processes in the plant [7]. This enzyme reacts very quickly with hydrogen peroxide compared with typical plant peroxidases [8]. The level of catalase activity is a specific marker of physiological stresses occurring throughout the plant [9], including the seeds.

The aim of the study was to evaluate the effect of increasing levels of macronutrients used to fertilize red amaranth on the level of catalase activity in its leaves at different developmental stages and in its seeds.

\section{Material and methods}

A field experiment was carried out in 2008 in the village of Bodaczów near Zamość (N - 50 $\left.0^{\circ} 1^{\prime}, \mathrm{E}-23^{\circ} 04^{\prime}\right)$. It was conducted on brown soil derived from loess with high content of phosphorus $\left(64 \mathrm{mg} \cdot \mathrm{kg}^{-1}\right)$, potassium $\left(125 \mathrm{mg} \cdot \mathrm{kg}^{-1}\right)$ and magnesium $\left(75 \mathrm{mg} \cdot \mathrm{kg}^{-1}\right)$. The soil was slightly acidic $\left(\mathrm{pH}_{\mathrm{KCl}}-6.0\right)$, with sorption capacity of $199.7 \mathrm{mmol}(+) \cdot \mathrm{kg}^{-1}$ and organic carbon content of about $30.2 \mathrm{~g} \cdot \mathrm{kg}^{-1}$ soil. The aim of the study was to determine the effect of increasing levels of NPK on catalase activity (per gram fresh weight) in the leaves of two varieties of red amaranth (Rawa and Aztek) at different developmental stages, as well as in its seeds.

The experiment was set up in a random split-plot design with three replicates. The following combinations of levels of macronutrients were used:

1) $50 \mathrm{~kg} \mathrm{~N} \cdot \mathrm{ha}^{-1}, 40 \mathrm{~kg} \mathrm{P} \mathrm{kg} \cdot \mathrm{ha}^{-1}, 40 \mathrm{~kg} \mathrm{~K} \mathrm{~kg} \cdot \mathrm{ha}^{-1}$

2) $70 \mathrm{~kg} \mathrm{~N} \cdot \mathrm{ha}^{-1}, 50 \mathrm{~kg} \mathrm{P} \mathrm{kg} \cdot \mathrm{ha}^{-1}, 50 \mathrm{~kg} \mathrm{~K} \mathrm{~kg} \cdot \mathrm{ha}^{-1}$

3) $90 \mathrm{~kg} \mathrm{~N} \cdot \mathrm{ha}^{-1}, 60 \mathrm{~kg} \mathrm{P} \mathrm{kg} \cdot \mathrm{ha}^{-1}, 60 \mathrm{~kg} \mathrm{~K} \mathrm{~kg} \cdot \mathrm{ha}^{-1}$

4) $130 \mathrm{~kg} \mathrm{~N} \cdot \mathrm{ha}^{-1}, 70 \mathrm{~kg} \mathrm{P} \mathrm{kg} \cdot \mathrm{ha}^{-1}, 70 \mathrm{~kg} \mathrm{~K} \mathrm{~kg} \cdot \mathrm{ha}^{-1}$

Nitrogen was applied twice (before sowing and during the intensive growth period) in the form of ammonium nitrate. The results obtained were compared with the control (without NPK fertilizer). The levels of phosphorus and potassium applied were also varied.

Amaranth seeds were sown on 24 May 2008 at wide-row spacing, every $60 \mathrm{~cm}$. The area of the microplots from which the plants were to be harvested was $1 \mathrm{~m}^{2}$. The plants were cultivated in accordance with proper horticulture procedures.

The material for testing was collected at the following stages of growth: seedling (3 June), five-leaf (24 June), flowering (3 August), and mature seed (20 September).

At each stage of growth, samples were taken from 10 randomly selected plants on each microplot. Catalase activity in the leaves (per gram fresh weight) was determined by the modified Beck method [10]. The freshly harvested leaves were finely chopped, 0.1g was weighed out, the sample was homogenized, and catalase activity was determined using $3 \% \mathrm{H}_{2} \mathrm{O}_{2}$. Five assays were made for each microplot and stage of development and the results were averaged. Catalase activity in the amaranth seeds was determined in the same manner, using $0.1 \mathrm{~g}$ homogenized seeds per assay. The results were analysed statistically 
using SAS 9.2 from Enterprise Guide 4.2. and the least significant differences were calculated using Tukey's test with a $5 \%$ risk of error. Correlation coefficients were calculated as well.

\section{Results and discussion}

No detailed studies have been conducted on how catalase activity in amaranth leaves at different developmental stages is affected by variations in macronutrient fertilization. This research could be very significant, as amaranth leaves can be used as a vegetable in people's daily diet. The research could make it easier to determine what levels of macronutrients are harmless when used in growing amaranth, both for use as a vegetable and for animal feed. The present study showed that catalase activity in the amaranth leaves changed during the vegetation period. It was significantly dependent on the stage of development, the variety of amaranth, and the level of macronutrients applied (Table 1). At each of the developmental stages investigated, the highest level of catalase activity in the leaves was noted in the microplots with the highest level of NPK, and the values were higher for the Rawa variety than for Aztek (Table 1). Significant dependencies were also observed between the stages of development and the level of catalase activity. The highest catalase activity per gram fresh weight was noted in the leaves at the seedling stage, in both the Rawa and the Aztek varieties. There was a noticeable decrease in catalase activity during the vegetation period. At the seedling stage, catalase activity per gram fresh weight in leaves from the control plots with the Rawa variety was $0.50 \mathrm{~cm} \cdot \mathrm{min}^{-1}$ (Table 1). Combination I of NPK applied in the microplots with the Rawa variety caused a $40 \%$ increase in catalase activity compared with the control. The increase in catalase activity was $50 \%$ when Combination II was applied, $64 \%$ for Combination III, and $88 \%$ for Combination IV (Table 1).

Table 1

Catalase activity per gram fresh weight of amaranth leaves - average values

\begin{tabular}{|c|c|c|c|c|}
\hline \multirow{3}{*}{$\begin{array}{c}\text { Macronutrient } \\
\text { levels }\end{array}$} & \multicolumn{4}{|c|}{ Catalase activity $\left[\mathrm{cm} \cdot \mathrm{min}^{-1}\right]$} \\
\hline & \multicolumn{4}{|c|}{ Stages of development } \\
\hline & Seedling & Five-leaf & Flowering & Mature seed \\
\hline \multicolumn{5}{|c|}{ Rawa variety } \\
\hline I combination & 0.70 & 0.55 & 0.30 & 0.25 \\
\hline II combination & 0.75 & 0.70 & 0.35 & 0.30 \\
\hline III combination & 0.82 & 0.75 & 0.60 & 0.48 \\
\hline IV combination & 0.94 & 0.84 & 0.76 & 0.60 \\
\hline Object of control & 0.50 & 0.35 & 0.25 & 0.20 \\
\hline \multicolumn{5}{|c|}{ Aztek variety } \\
\hline I combination & 0.65 & 0.40 & 0.25 & 0.16 \\
\hline II combination & 0.70 & 0.55 & 0.40 & 0.25 \\
\hline III combination & 0.76 & 0.60 & 0.52 & 0.30 \\
\hline IV combination & 0.85 & 0.72 & 0.60 & 0.40 \\
\hline Object of control & 0.50 & 0.25 & 0.17 & 0.14 \\
\hline $\begin{array}{l}\mathrm{LSD}_{0.05} \\
\text { variety } 0.049 \\
\text { fertilization } 0.045 \\
\text { stages of developme }\end{array}$ & & & & \\
\hline
\end{tabular}


Catalase activity per gram fresh weight in the Aztek seedlings from the control plots was, as in the Rawa variety, $0.50 \mathrm{~cm} \cdot \mathrm{min}^{-1}$ (Table 1). Combination I of NPK applied in the microplots with Aztek caused a 30\% increase in catalase activity. The increase was $40 \%$ in the case of Combination II, 52\% for Combination III, and 70\% for Combination IV (Table 1). The tests conducted at the five-leaf stage also showed that Rawa plants from the control plots had higher catalase activity per gram fresh weight than the Aztek variety. Increasing levels of NPK led to an increase in catalase activity. In the microplots with the Rawa variety, Combination I led to a $57.1 \%$ increase in catalase activity in the leaves; the increase was $100 \%$ for Combination II, $114.3 \%$ for Combination III, and $140 \%$ for Combination IV (Table 1). The lowest level of NPK applied in the microplots with the Aztek variety caused a $60 \%$ increase in catalase activity in the leaves. The increase was $120 \%$ in the case of Combination II, $140 \%$ for Combination III, and 188\% for Combination IV (Table 1).

Table 2

Catalase activity in amaranth seeds - average values

\begin{tabular}{|c|c|}
\hline Macronutrient levels & Catalase activity $\left[\mathbf{c m} \cdot \mathbf{~ m i n}^{\mathbf{- 1}}\right]$ \\
\hline \multicolumn{2}{|c|}{ Rawa variety } \\
\hline I combination & 0.70 \\
\hline II combination & 0.82 \\
\hline III combination & 0.90 \\
\hline IV combination & 0.95 \\
\hline Object of control & 0.65 \\
\hline I combination & 0.70 \\
\hline II combination & 0.75 \\
\hline III combination & 0.85 \\
\hline IV combination & 0.89 \\
\hline Object of control & 0.60 \\
\hline $\begin{array}{l}\text { LSD } \\
\text { variety } 0.012 \text { ariety } \\
\text { fertilization } 0.013\end{array}$ \\
\hline
\end{tabular}

Catalase activity per gram fresh weight in the leaves from the flowering stage was $0.25 \mathrm{~cm} \cdot \mathrm{min}^{-1}$ in the case of the Rawa variety of amaranth, and $0.17 \mathrm{~cm} \cdot \mathrm{min}^{-1}$ for the Aztek variety (Table 1). In the Rawa variety, Combination I caused a $20 \%$ increase in catalase activity; the increase was $40 \%$ for Combination II, $140 \%$ for Combination III and $204 \%$ for Combination IV (Table 1). In the case of the Aztek variety, Combination I of NPK caused a $47.1 \%$ increase in catalase activity in the leaves; the increase was $153.3 \%$ for Combination II, 205.9\% for Combination III, and 252.9\% for Combination IV (Table 1). At the mature seed stage, catalase activity in the amaranth leaves from the control plots was $0.20 \mathrm{~cm} \cdot \mathrm{min}^{-1}$ in the case of Rawa variety and $0.14 \mathrm{~cm} \cdot \mathrm{min}^{-1}$ in the case of the Aztek variety (Table 1). When Combination I of NPK was applied in the microplots with the Rawa variety, catalase activity in the leaves increased by $25 \%$; the increase was $50 \%$ in the case of Combination II, $140 \%$ for Combination III, and $200 \%$ for Combination IV (Table 1). In the Aztek variety, Combination I of NPK caused a $14.3 \%$ increase in catalase activity; the increase was $78.6 \%$ for Combination II, $114.3 \%$ for Combination III, and $185.7 \%$ for Combination IV (Table 1). Catalase activity in the seeds of the Rawa variety from the control plots was $0.65 \mathrm{~cm} \cdot \mathrm{min}^{-1}$, while in the Aztek variety it was $0.60 \mathrm{~cm} \cdot \mathrm{min}^{-1}($ Table 
2). Application of increasing levels of macronutrients led to an increase in catalase activity in the seeds of both the Rawa and the Aztek variety. Combination I of the fertilizers led to a $7.7 \%$ increase in catalase activity in the Rawa seeds; the increase was $26.2 \%$ for Combination II, $38.5 \%$ for Combination III and $46.2 \%$ for Combination IV (Table 2). The lowest level of macronutrients produced a $16.7 \%$ increase in catalase activity in the seeds of the Aztek variety of red amaranth; the increase was $25 \%$ for Combination II, $41.7 \%$ for Combination III and $48.6 \%$ for Combination IV (Table 2).

The study shows that micronutrient fertilization significantly affected the level of catalase activity in the amaranth leaves, at all stages of development, as well as in the seeds. This was also indicated by the high positive correlation coefficients (Table 3). Probably the most significant effect in the experiment was that of fertilization with nitrogen. Increasing levels of macronutrient fertilizers usually increase oxidative stress parameters [11], but can affect the level of non-enzymatic antioxidants in a plant in different ways [12]. The quantity and quality of the yield of various plants is affected by both deficiencies and excesses of minerals in the soil [13] and by salinity of the substrate [12]. Amaranth does not require very high levels of nitrogen fertilizer. The levels of nitrogen most often recommended for the plant range from 90 to $120 \mathrm{~kg} \mathrm{~N} \cdot \mathrm{ha}^{-1}[5,6]$. Studies show that nitrogen is the main factor limiting production of amaranth grain [14]. Optimization of nitrogen fertilization of amaranth crops requires many more years of research and elucidation. Elbehri et al [14] point out that the effectiveness of nitrogen utilization by amaranth grain decreases as soil nitrogen increases.

Table 3

Correlation coefficients between combinations of fertilization and catalase activity

\begin{tabular}{|c|c|c|c|c|c|}
\hline \multirow{3}{*}{ Parameters } & \multicolumn{5}{|c|}{ Catalase activity } \\
\hline & \multicolumn{5}{|c|}{ Stages of development } \\
\hline & Seedling & Five-leaf & Flowering & Mature seed & Seeds \\
\hline \multicolumn{6}{|c|}{ Rawa variety } \\
\hline $\begin{array}{l}\text { Combinations of } \\
\text { fertilization }\end{array}$ & $+0.997 *$ & $+0.979 *$ & $+0.917 *$ & $+0.934 *$ & $+0.956^{*}$ \\
\hline \multicolumn{6}{|c|}{ Aztek variety } \\
\hline $\begin{array}{c}\text { Combinations of } \\
\text { fertilization }\end{array}$ & $+0.998 *$ & $+0.988^{*}$ & $+0.964 *$ & $+0.952 *$ & $+0.979 *$ \\
\hline
\end{tabular}

${ }^{*} \mathrm{p}=0.01$

Schulte-Erley et al [15] obtained higher yield of amaranth grain by applying $120 \mathrm{~kg} \mathrm{~N} \cdot \mathrm{ha}^{-1}$. According to Myers [16], nitrogen applied at a higher level than what is recommended, $180 \mathrm{~kg} \mathrm{~N} \cdot \mathrm{ha}^{-1}$, caused a $42 \%$ increase amaranth grain yield compared with the control, in which the plants were not fertilized with nitrogen. Fertilization with high levels of nitrogen - over $180 \mathrm{~kg} \mathrm{~N} \cdot \mathrm{ha}^{-1}$ - negatively affected grain yield in three varieties of amaranth: Plainsman, D136 and K266. High levels of nitrogen negatively affected grain quality; the plants entered the flowering stage later and the moisture content of the seeds increased. Moreover, the amaranth plants exhibited excessive growth. Saini and Shekhar [17] believe that $90 \mathrm{~kg} \mathrm{~N} \cdot \mathrm{ha}^{-1}$ is the optimum level for amaranth crops. After applying this level of nitrogen they noted higher leaf-area index, effective plant population, flower-head length, 1,000-seed weight and harvest index than in the control. Nitrogen utilization depends on the variety of amaranth and on growing conditions [18]. Five levels of nitrogen 
fertilizer were used in growing the NH84/593-1 and NH84/594 varieties of amaranth: 0,15 , 30,45 and $60 \mathrm{~kg} \mathrm{~N} \cdot \mathrm{ha}^{-1}$. The height of the plants, number of leaves, dry weight yield from the leaves and stems, and grain yield increased substantially as the level of nitrogen increased from 0 to $45 \mathrm{~kg} \mathrm{~N} \cdot \mathrm{ha}^{-1}$.

The level of nitrogen fertilization also affects the accumulation of chlorophyll in the leaves. Too much nitrogen leads to a significant reduction in chlorophyll $a$ and $a+b$ [19]. Skwarylo-Bednarz and Krzepilko [20] demonstrated that increasing levels of nitrogen used to fertilize two varieties of amaranth, Rawa and Aztek, grown at narrow-row spacing, significantly influenced chlorophyll $a$ content per gram fresh weight in the leaves. The highest level of chlorophyll $a$ in the leaves of the Rawa variety was noted after application of $90 \mathrm{~kg} \mathrm{~N} \cdot \mathrm{ha}^{-1}$, and in the Aztek leaves when $70 \mathrm{~kg} \mathrm{~N} \cdot \mathrm{ha}^{-1}$ was applied. The highest levels of chlorophyll $b$ were observed in the Rawa leaves after applying $70 \mathrm{~kg} \mathrm{~N} \cdot \mathrm{ha}^{-1}$, and in the Aztek leaves after fertilization with $90 \mathrm{~kg} \mathrm{~N} \cdot \mathrm{ha}^{-1}$. Application of $130 \mathrm{~kg} \mathrm{~N} \cdot \mathrm{ha}^{-1}$ led to a reduction in chlorophyll $a$ and $a+b$ in both varieties. A significant dependence between nitrogen fertilization and chlorophyll $a$ and $a+b$ content was also noted when the two varieties of amaranth were grown at wide-row spacing [21].

Improperly balanced mineral fertilization usually results in the occurrence of highly reactive free radicals which damage cellular macromolecules [22]. Antioxidants and oxidative stress enzymes participate in the acclimatization of plants to unfavourable environmental conditions. Catalase is one of the enzymes constituting the first line of defence [7]. Its activity increases very quickly during the action of a stress factor. Environmental stress not only significantly affects the growth and development of plants, but also induces generation of reactive oxygen species (ROS) in cells and tissues. Excess supply of ammonium ions has been found to induce oxidative stress in the aquatic plant Egeria densa. Physiological responses of Egeria densa to high ammonium concentration and nitrogen deficiency [23]. High concentration of $\mathrm{NH}_{4}^{+}$led to a decrease in the concentration of chlorophyll, protein and soluble carbohydrates, but also increased typical oxidative stress parameters such as MDA concentration and activity of SOD, peroxidase and catalase. Ammonium ions added at high concentrations for several days led to an increase in catalase activity. Moreover, a decrease in biomass was observed, which suggests that the stress induced by $\mathrm{NH}_{4}+$ directly influences growth efficiency.

Antioxidant enzyme activity and free radical concentration may be an indicator of stress induced by high temperature in A. lividus seedlings [24]. In amaranth seeds that germinated at $45^{\circ} \mathrm{C}$, parameters characteristic of stress were observed: reduced germination rate and energy, poorer growth, changes in antioxidant enzyme activity, and increased concentration of hydrogen peroxide. Antioxidant enzyme activity decreased in proportion to the duration of heat shock during the early germination period. A substantial reduction in catalase activity was noted in seedlings subjected to a temperature of $45^{\circ} \mathrm{C}$ for 12 hours. In a study on the level of catalase activity in the rhizosphere and non-rhizosphere of the soil on which amaranth was grown under conditions of varied macronutrient fertilization, it was demonstrated that excessive mineral fertilization, particularly at the high level of $130 \mathrm{~kg} \mathrm{~N} \cdot \mathrm{ha}^{-1}$, can act as a stress factor [25].

The data obtained (Table 1) suggest that the Aztek and Rawa varieties are sensitive to high levels of $\mathrm{N}$, which is manifested as an increase in catalase activity [26]. A stimulating effect of macronutrient fertilization on catalase activity has also been observed in various 
organs of crop plants: in the leaves of wheat [27, 28], in potato tubers [7], and in cabbage [29]. Vanacker et al [30] also demonstrated a decrease in catalase activity in the leaves of Pisum sativum L. after 12 weeks of an experiment in conditions of varied nitrogen fertilization. Nitrogen fertilizer can alleviate toxic effects induced by other factors [31]. A study on the effect of nitrogen fertilization on rapeseed grown on sediments contaminated with boron showed that increasing the concentration of nitrogen is conducive to biomass production and alleviates boron-induced oxidative stress. One of the stress parameters determined was catalase activity, which decreased significantly on the contaminated substrate. A high level of nitrogen fertilizer mitigated this negative effect of boron, causing an increase in catalase activity.

Studies by many authors have shown that mineral fertilizer causes an increase in antioxidant compounds in plants [32, 33]. One such compound is vitamin $\mathrm{C}$, whose accumulation in fruits and vegetables is aided by nitrogen fertilization [32].

\section{Conclusions}

1. Catalase activity in the amaranth leaves exhibited a downward trend during the vegetation period of the plants. The highest activity was noted during the first stage, $i e$ the seedling stage.

2. Fertilization with increasing levels of macronutrients significantly increased catalase activity per gram fresh weight in the leaves at each developmental stage, as well as in the seeds.

3. The two amaranth varieties had significantly different levels of catalase activity. The Rawa variety had higher catalase activity than the Aztek variety.

\section{References}

[1] Prokopowicz D. Health properties of amaranth (Amaranthus cruentus) (in Polish). Medycyna Wet. 2001;57(8):559-561.

[2] Skwaryło-Bednarz B, Brodowska MS. Amaranth (Amaranthus cruentus L.) as a plant with pro-health properties. In: Elements, the environment and human life. Pasternak K. editor. Lublin: Wyd Polskie Towarzystwo Magnezologiczne, 2009:280-287.

[3] Paśko P, Bednarczyk M. Amaranthus sp.: its possible application in medicine (in Polish). Bromat Chem Toksykol. 2007;XL(2):217-222.

[4] Grajeta H. Nutrition value and utilization of amaranth (in Polish). Bromat Chem Toksykol. 2007;XXX(1):17-23.

[5] Skwaryło-Bednarz B, Nalborczyk E. Cultivation and utilization of amaranth (in Polish). Wieś Jutra. 2006;4(93):52-55.

[6] Gontarczyk M. Cultivated amaranth (Amaranthus spp). In: New crop plants for consumption and industrial purposes and as renewable energy sources (in Polish). Warsaw: Wyd SGGW;1996:21-43.

[7] Mioduszewska $\mathrm{H}$. The effect of nitrogen fertilization on peroxidase and catalase activity in tubers of the potato cv. Uran (in Polish). Biuletyn IHAR. 2001;220:215-220.

[8] Bartosz G. The Other Face of Oxygen. Free Radicals in Nature (in Polish). Warsaw: Wyd PWN. 2009:174.

[9] Szymczak J, Kłódka D, Smolik B, Pawlica M. Effect of cadmium salt on the activity of oxidative stress enzymem in soil and maize (Zea mays var. saccharata). Ochr Środow i Zasob Natural. 2011;48:210-215.

[10] Brauner L, Bukatsch F. Praktikum in Plant Phisiology (in Polish). Warsaw: Wyd PWN; 1987:36-37.

[11] Gurgul E, Herman B. Influence of nitrogen, phosphorus and potassium on chemical composition and activity of some enzymes in celery during its growth (in Polish). Biologia Plantarum. 1994;36(2):261-265.

[12] Telesiński A, Nowak J, Smolik B, Dubowska A, Skrzypiec N. Effect of soil sainity on activity of antioxidant enzymes and content of ascorbic acid and phenols in bean (Phaseolus vulgaris L.) plants. J Elementol. 2008;13(3):401-409. 
[13] Starck Z, Chołuj D, Niemyska B. Physiological reactions of plants to detrimental environmental factors (in Polish). Warsaw: Wyd SGGW; 1995:95-103.

[14] Elbehri A, Putnam DH, Schmidt M. Nitrogen fertilizer and cultivar effects on yield and nitrogen-use efficiency of grain amaranth. Agron J. 1993;85:120-128. DOI: 10.2134/agronj1993.00021962008500010023x.

[15] Schulte-Erley G, Kaul H-P, Kruse M, Aufhammer W. Yield and nitrogen utilization efficiency of the pseudocereals amaranth, quinoa and buckwheat under differing nitrogen fertilization. Eur J Agron. 2005;22:95-100. DOI: org/10.1016/j.eja.2003.11.002.

[16] Myers RL. Nitrogen fertilizer effect on grain amaranth. Agron J. 1998;90(5):597-602. DOI: 10.2134/agronj1998.00021962009000050005x.

[17] Saini JP, Shekhar J. Effect of nitrogen fertilizer on growth and yield of grain amaranth (Amaranthus hypochondriacus) cultivars under dry-temperate condition. Indian J of Agronomy. 1998;43(4):743-746.

[18] Olaniyi OJ, Adelasoye KA, Jegede CO. Influence of nitrogen fertilizer on the growth, yield and quality of grain amaranth varieties. World J of Agricult Sci. 2008;4(4):506-513.

[19] Szulc P, Rybus-Zając M, Waligóra H, Skrzypczak W. Effect of Fusarium culmorum on the content of chlorophyll in dependence on doses of nitrogen and the method of fertilization (in Polish). Acta Agrophys. 2008;11(2):519-526.

[20] Skwaryło-Bednarz B, Krzepiłko A. Effect of various doses on NPK fertilizers on chlorophyll content in the leaves of two varietes of amaranth (Amaranthus cruentus L.). Ecol Chem Eng A. 2009;16:10:1373-1378.

[21] Skwaryło-Bednarz B, Krzepiłko A. Effect of various doses on NPK fertilizers on chlorophyll content in the leaves of two varietes of amaranth (Amaranthus cruentus L.) in wide-row cultivation (in Polish). Acta Agrophys. 2009;14(2):469-477.

[22] Łata B, Przeradzka M, Stojanowska J. Nitrogen dependent changes in low molecular weigh thiols, ascorbate, antioxidative enzymes activity in brocoli and cauliflower (in Polish). Roczniki Akademii Rolniczej w Poznaniu - CCCLVI. 2004:143-151.

[23] Shengqi S, Yiming Z, Jian GQ, Wei W, Weizhi Y, Liang S. Physiological responses of Egeria densa to high ammonium concentration and nitrogen deficiency. Chemosphere. 2012;86(5):538-545. DOI: 10.1016/j.chemosphere.2011.10.036.

[24] Bhattacharjee S, Mukherjee AK. Implications of reactive oxygen species in heat shock induced germination and early growth impairment in Amaranthus lividus L. Biologia Plantarum. 2003;47(4):517-522. DOI: 10.1023/B:BIOP.0000041055.77873.db.

[25] Skwaryło-Bednarz B, Krzepiłko A. The effect of various NPK fertilizer doses on total antioxidant capacity of soil and amaranth leaves (Amaranthus cruentus L.). Internat Agrophys. 2009;23(1):61-66.

[26] Okuda T, Matsuda Y, Sagisaka S. Abrupt increase in the level of hydrogen peroxide in leaves of winter wheat in caused by cold treatment. Plant Physiol. 1991;97:1265-1267.

[27] Kaczmarczyk S, Kostańska E, Ścieżko D, Roy M. The course of certain photosynthetic processes and yield of winter wheat and triticale (in Polish). Acta Agrobot. 1993;46:31-38.

[28] Polesskaya OG, Kashirina EI, Alekhina ND. Changes in the activity of antioxidant enzymes in wheat leaves and roots as a function of nitrogen source and supply. Russian J of Plant Physiol. 2004;51(5):615-620.

[29] Gurgul E, Kołota E, Ścieżko D. An attempt to determine the dependence between activity of certain enzymes and the level of nitrogen fertilization as well as yield of irrigated and non-irrigated cabbage (in Polish). Zesz Nauk AR Szczecin. 1980;24(85):33-42.

[30] Vanacker H, Sandalio LM, Jiménez A, Palma JM, Corpas FJ, Meseguer V, et al. Roles for redox regulation in leaf senescence of pea plants grown on different sources of nitrogen nutrition. J of Experim Botany. 2006;57(8):1735-1745. DOI: 10.1093/jxb/erl012.

[31] Giansoldatia V, Tassia E, Morellib E, Gabellierib E, Pedrona F, Barbafieri M. Nitrogen fertilizer improves boron phytoextraction by Brassica juncea grown in contaminated sediments and alleviates plant stress. Chemosphere. Available online 2012. http://dx.doi.org/10.1016/j.chemosphere.2012.02.005.

[32] Nurzyńska-Wierdak R. The effect of varied nitrogen fertilization on the yield and chemical composition of rocket (Eruca sativa Mill.) grown in autumn (in Polish). Acta Scienti Polon - Hortorum Cultus. 2006;5(2):53-63.

[33] Skwaryło-Bednarz B, Krzepiłko A. Effect of different fertilization on enzyme activity in rhizosphere and non-rhizosphere of amaranth. Internat Agrophys. 2009;23(4):409-412. 


\title{
WPŁYW ZRÓŻNICOWANEGO NAWOŻENIA NPK NA AKTYWNOŚĆ KATALAZY AMARANTUSA (Amaranthus cruentus L.)
}

\author{
Wydział Nauk Rolniczych w Zamościu, Uniwersytet Przyrodniczy w Lublinie
}

\begin{abstract}
Abstrakt: Badano wpływ zróżnicowanego nawożenia NPK na aktywność katalazy w świeżej masie liści dwóch odmian amarantusa (Rawa i Aztek) w różnych fazach rozwojowych (faza siewki, faza piątego liścia, faza pełni kwitnienia i faza pełni dojrzałości nasion) oraz w nasionach. W doświadczeniu polowym uprawiano szarłat w rozstawie szerokorzędowej na glebie kompleksu pszennego dobrego, w południowo-wschodniej części Polski. Zastosowano następujące kombinacje dawek makroskładników: I - $50 \mathrm{~kg} \mathrm{~N} \cdot \mathrm{ha}^{-1}, 40 \mathrm{~kg} \mathrm{P} \cdot \mathrm{ha}^{-1}, 40 \mathrm{~kg} \mathrm{~K} \cdot \mathrm{ha}^{-1}$, II - $70 \mathrm{~kg} \mathrm{~N} \cdot \mathrm{ha}^{-1}, 50 \mathrm{~kg} \mathrm{P} \cdot \mathrm{ha}^{-1}, 50 \mathrm{~kg} \mathrm{~K} \cdot \mathrm{ha}^{-1}, \mathrm{III}-90 \mathrm{~kg} \mathrm{~N} \cdot \mathrm{ha}^{-1}, 60 \mathrm{~kg} \mathrm{P} \cdot \mathrm{ha}^{-1}, 60 \mathrm{~kg} \mathrm{~K} \cdot \mathrm{ha}^{-1}$ oraz $^{-1}$ IV - $130 \mathrm{~kg} \mathrm{~N} \cdot \mathrm{ha}^{-1}, 70 \mathrm{~kg} \mathrm{P} \cdot \mathrm{ha}^{-1}, 70 \mathrm{~kg} \mathrm{~K} \cdot \mathrm{ha}^{-1}$. Z przeprowadzonych badań wynika, iż aktywność katalazy wykazywała tendencję malejącą w okresie wegetacji amarantusa. Najwyższą aktywnością katalazy cechowała się świeża masa liści w pierwszej badanej fazie - fazie siewki. Wzrostowi aktywności katalazy sprzyjało nawożenie wzrastającymi dawkami NPK. Liście odmiany Rawa cechowały się większą aktywnością katalazy niż Aztek i to niezależnie od fazy rozwojowej. Na poziom aktywności katalazy w nasionach amarantusa istotny wpływ miało także nawożenie oraz odmiana. Większe dawki nawozów powodowały wzrost poziomu aktywności katalazy w nasionach.
\end{abstract}

Słowa kluczowe: amarantus, aktywność katalazy, liście, nasiona 